\title{
Four Dozen Key Resources on Apologetics and Natural Theology in an Age of Science
}

\author{
Curated and annotated by Peter S. Williams \\ Assistant Professor in Communication and Worldviews \\ NLA University College \\ peterswilliams@gmail.com
}

I was both delighted and daunted when Chief Editor Lars Dahle invited me to compile a bibliography for this special Supplement edition of Theofilos on 'Science, Natural Theology, and Christian Apologetics'.

Of course, these days a literal interpretation of 'bibliography' would preclude mentioning some of the many excellent resources available in the form of video and audio material via platforms such as the internet, and so I've chosen to provide the following list of key 'resources' under several sub-headings. Each resource is followed by a brief description.

The title of this list was inspired by Alvin Plantinga's famous paper on 'Two dozen (or so) arguments for God', with four dozen recommendations giving room for covering the wide variety of issues that fall within the remit of 'apologetics and natural theology in an age of science', without becoming too unwieldy.

Key Documentary Series:

The God Question: The Series/Science vs God? (Dir. Ian Morris.):

www.thegodquestion.tv

The website for the series provides study guides, leaders guides, and materials for schools.

See also: Peter S. Williams \& Lars Dahle, 'Turning Back the Tide of Atheism with the God Question' https://youtu.be/wBWYvCBRYYw https://foclonline.org/talk/turning-backtide-atheism-god-question

\section{Key Websites:}

Reasonable Faith Website: www.reasonablefaith.com

This leading Christian apologetics website showcases the work of William Lane Craig.
Peter S. Williams' YouTube Channel, Curated Playlists:

www.youtube.com/user/peterswilliamsvid/playlists?flow=grid $\&$ view $=1$

Over 125 curated YouTube playlists on a wide variety of apologetic and philosophical subjects.

\section{Key Podcasts:}

Reasonable Faith Podcast: www.reasonablefaith.org/media/reasonable-faith-podcast/

William Lane Craig's interview style podcast.

Unbelievable? www.premierchristianradio. com/Shows/Saturday/Unbelievable

In this program from Premier Christian

Radio, Justin Brierley ably hosts discus- 
sion between guests with differing ideas about important issues.

The Peter S. Williams Podcast: http://podcast.peterswilliams.com

This apologetics podcast often covers issues related to science, natural theology, and Christian apologetics

\section{Key Texts:}

Barrett, Matthew, Ardel B. Caneday and Stanley N. Gundry ed.'s. Four Views On The Historical Adam (Zondervan, 2013)

Denis O. Lamoureux, John H. Walton, C. John Collins and William D. Barrick have a four-way discussion about how to understand the Biblical figure of Adam.

Bassham, Gregory ed. C.S. Lewis's Christian Apologetics: Pro and Con (Brill/Rodopi, 2015)

A series of short debates over arguments drawn from the works of C.S. Lewis. The debate between Bassham and Peter S. Williams over the argument from desire is continued by the latter in "In Defence of Arguments From Desire" (2016) www.peterswilliams.com/2016/11/02/ in-defence-of-arguments-from-desire/.

Blomberg, Craig and Carl Stecher, with contributions by Richard Carrier and Peter S. Williams, Resurrection: Faith or Fact? A Scholars' Debate Between a Skeptic and a Christian (Pitchstone, 2019)

This written debate on the resurrection is the only such volume published by a non-Christian publisher. See also:

Peter S. Williams, 'Resurrection:

Faith or Fact? Miracle Not Required?'

Theofilos vol.11, nr 2 (2019)

https://theofilos.no/wp-content/uploads/ 2020/03/Theofilos-vol.-11-nr.-2-2019-

Forum-3-Arkiv.pdf.

Copan, Paul and William Lane Craig, ed.'s. The Kalam Cosmological Argu- ment, Volume 2: Scientific Evidence

for the Beginning of the Universe

(Bloomsbury Studies in Philosophy of Religion, 2019)

This collection of papers reviews and assesses the latest scientific evidences for the universe's beginning and ends with an examination of the kalam argument's conclusion that the universe has a cause - a personal cause with properties of theological significance.

Copan, Paul and Charles Taliaferro, ed.'s. The Naturalness of Belief:

New Essays on Theism's Rationality

(Lexington, 2018)

Beginning with naturalist Graham Oppy's own account of the naturalness of a naturalistic worldview, this wideranging collection of papers defends the naturalness of theism in light of consciousness, intentionality, beauty, human dignity, free will, rationality, and knowledge; as well as looking at commonsensical, existential, psychological, and cultural reasons, in addition to insights from the cognitive science of religion.

Copan, Paul et al ed.'s. Dictionary of Christianity and Science (Zondervan, 2017)

Billing itself as "The definitive reference for the intersection of Christian faith and contemporary science", this multiauthor work by over 140 leading international scholars includes "Multipleview essays on controversial topics" and entries on over 450 key terms, theories, individuals and subjects of debate.

Copan, Paul and Paul Moser, ed.'s. The Rationality of Theism (Routledge, 2003)

A good collection of introductory/intermediate level papers. Part One addresses foundational issues about religious language and epistemology. Part Two focuses on arguments for God's existence, including the ontological argument, the cosmological argument, the teleological argument, and miracles. In Part Three examines arguments 
against theism from the divine attributes and the existence of evil.

Cowen, Steven B. ed. Five Views on Apologetics (Zondervan, 2000)

Brings leading exponents of five different apologetic methodologies into dialogue.

Craig, William Lane. On Guard for Students: A Thinker's Guide to the Christian Faith (David C. Cooke, 2015)

The foremost apologist of our times writes an accessible book aimed at non-Christian readers.

Craig, William Lane and J.P. Moreland ed.'s. The Blackwell Companion to Natural Theology (Wiley-Blackwell, 2009)

Substantial essays on different aspects of natural theology written by leading philosophers.

Craig, William Lane and J.P. Moreland ed.'s. Naturalism: A Critical Analysis

(Routledge, 2014)

A stellar collection of papers that put the debate about theism in the context of arguments against metaphysical naturalism.

Dembski, William A. and Jonathan Wells. The Design of Life: Discovering Signs of Intelligence in Biological Systems (ISI, 2007)

An engaging intermediate level introduction to intelligent design theory within the biological sciences.

Gordon, Bruce L and William A. Dembski, ed.'s. The Nature of Nature: Examining the Role of Naturalism in Science (ISI, 2010)

A large collection of papers, from different perspectives, on naturalism in science.

Gundry, Stanley N. and J.B. Stump ed.'s. Four Views on Creation, Evolution, and Intelligent Design (Zondervan, 2017)
Representatives from Answers in Genesis, Reasons to Believe, BioLogos and the Discovery Institute dialogue over their different models of origins.

Hannam, James. The Genesis of Science: How the Christian Middle Ages

Launched the Scientific Revolution

(Regnery, 2011)

Sets straight the record about the relationship between Christianity and science in the middle ages.

Holder, Rodney. Ramified Natural Theology in Science and Religion:

Moving Forward from Natural

Theology (Routledge, 2021)

Uses Bayesian confirmation theory to defend a 'ramified natural theology' in dialogue with both science and historical-critical study of the Bible.

Kitchen, K.A. On the Reliability of the Old Testament (Eerdmans, 2006)

A robust defence of the historical reliability of the Old Testament by an eminent Egyptologist.

Larmer, Robert A. The Legitimacy of

Miracle (Lexington, 2014)

A brilliant philosophical defense of miracles.

Lennox, John C. God's Undertaker: Has Science Buried God?, second edition (Lion, 2009)

A winsome rejection of the popular idea that modern science has "buried" God.

Licona, Michael R. The Resurrection of Jesus: A New Historiographical Approach (IVP/Apollos, 2010)

This substantial monograph by a protégé of Gary R. Habermas leans over backwards to avoid confirmation bias and is noteworthy for its careful discussion of historical methodology.

Menuge, Angus. Agents under Fire: Materialism and The Rationality of Science (Rowman \& Littlefield, 2004) 
Philosopher Menuge relates intelligent design theory to the philosophy of mind, arguing that irreducible complexity challenges reductionist accounts of human psychology as well as reductionism in biology.

Meyer, Stephen C. The Return of The God Hypothesis: Three Scientific Discoveries Revealing the Mind Behind The Universe (HarperOne, 2021)

Philosopher of science and leading intelligent design theorist Stephen C. Meyer mounts an argument for theism.

Miller, Corey and Paul Gould, ed.'s. Is Faith in God Reasonable? (Routledge, 2014)

Begins with the transcription of a debate between William Lane Craig and Alex Rosenberg, adds several commenting papers, and gives the debaters the opportunity to respond.

Monton, Bradley. Seeking God in Science: An Atheist Defends Intelligent Design Theory (Broadview Press, 2009)

Atheist philosopher of science Bradley Monton defends the scientific status of intelligent design theory and explains why its arguments make him less certain of his atheism.

Moreland, J.P. The Recalcitrant Imago Dei: Human Persons and the Failure of Naturalism (SCM, 2009)

A leading Christian philosopher, Moreland mounts a wide-ranging argument against naturalistic accounts of human beings.

Moreland, J.P. Consciousness and the Mind of God (Routledge, 2008)

Moreland is a leading proponent of the theistic argument from mind.

Moreland, J.P. Scaling the Secular City: A Defence of Christianity (Baker, 1987)

One of the finest one-volume apologetics of the twentieth century.
Moreland, J.P. and William Lane Craig.

Philosophical Foundations for a

Christian Worldview, second edition

(IVP, 2017)

Moreland and Craig join forces to write a high level 'introduction' to philosophical issues relevant to forming a synoptic Christian worldview. Includes chapters on arguments for God.

Moreland, J.P. and Kai Nielsen et al. Does God Exist?: The Debate Between Theists and Atheists (Prometheus, 1993)

An interesting if somewhat frustrating debate between Moreland and Nielsen. On the atheist side, there are also contributions from atheists Antony Flew and Keith Parsons; but the real value of this collection lies in William Lane Craig' incisive debate analysis, Dallas Willard's classic 'Language, Being, God, and the Three Stages of Theistic Evidence' and Peter Kreeft's introduction, concluding chapter and appendix - all designed to help readers decide for themselves whether God is fact or fantasy.

Nagasawa, Yujin. The Existence of God: A Philosophical Introduction (Routledge, 2011)

Leading philosopher of religion Yujin Nagasawa takes the arguments for God seriously in this well written introductory work suitable for undergraduates.

Nagel, Thomas. Mind \& Cosmos: Why the Materialist Neo-Darwinian Conception Of Nature Is Almost Certainly Wrong (Oxford, 2012)

A leading atheist philosopher of mind, Nagel made waves with this short book in which he critiques the orthodox naturalistic worldview of contemporary Western culture, says nice things about the proponents of Intelligent Design theory, discusses the problems of fitting consciousness into a naturalistic ontology, and hopes vaguely for a nontheistic teleological alternative. 
Plantinga, Alvin. Where the Conflict

Really Lies: Science, Religion, and

Naturalism (Oxford University Press, 2012)

Leading Christian philosopher Alvin Plantinga argues that science and theistic religion in concord, whereas science and naturalistic atheism are in conflict.

Polkinghorne, John C. Belief in God in an Age of Science (Yale, 2003)

Quantum physicist turned theologian John Polkinghorne's Terry Lectures focus on the collegiality between science and theology.

Ratzsch, Del. Science \& Its Limits: The Natural Sciences in Christian Perspective, second edition (IVP, 2000)

An accessible introduction to the philosophy of science.

Sennett, James F. and Douglas Groothuis, eds. In Defence of Natural Theology: A Post-Humean Assessment (IVP, 2005)

Collection of papers written in the light of David Hume's influential critique of natural theology.

Smart, J.J.C. and J.J. Haldane. Atheism \& Theism, second edition (Blackwell, 2003)

A wide-ranging written debate between two noted philosophers.

Swinburne, Richard. The Existence of God, second edition (Clarendon Press, 2004)

A pioneering inductive approach to natural theology from a leading Christian philosopher of religion.

Swinburne, Richard. The Resurrection of God Incarnate (Clarendon Press, 2003)

Swinburne applies his inductive approach to defending the resurrection of Jesus.

Walls, Jerry L. and Trent Dougherty ed.'s, The Plantinga Project: Two Dozen (Or So) Arguments for God (Oxford
University Press, 2018)

Papers from an academic conference inspired by Alvin Plantinga's seminal 1986 paper on "Two Dozen (Or So) Arguments for God", highlighting the breadth of contemporary natural theology.

Williams, Peter S. Outgrowing God? A Beginner's Guide to Richard Dawkins and the God Debate (Cascade Books, 2020)

Written in dialogue form, this response to atheist Richard Dawkins' book Outgrowing God encourages critical thinking about Professor Dawkins' arguments concerning God, Jesus, and the Bible. Several chapters interact with Dawkins on issues of science and natural theology, covering the moral argument, arguments from design in biology and cosmology, and the kalam cosmological argument.

Williams, Peter S. Getting at Jesus:

A Comprehensive Critique of Neo-Atheist Nonsense about the Jesus of History (Wipf and Stock, 2019)

This "comprehensive critique" of New Atheist views on the historical Jesus and the historical testimony concerning his life, death and resurrection draws on philosophy, history, archaeology and other scientific evidence to make a positive case for the Christian understanding of Jesus. It also shows how statements from neo-atheists can be used to defend the major elements of this understanding.

Williams, Peter S. A Faithful Guide to Philosophy: A Christian Introduction to the Love of Wisdom, reprint edition (Wipf and Stock, 2019)

This well-received Christian introduction to philosophy includes an unusually broad range of material on natural theology and a chapter on the relationship between science and theology. This reprint edition includes a new author's preface and a foreword by Angus Menuge. 